Volume : 05
Nomor : 03
Bulan : September
Tahun : 2019
http://ejurnal.pps.ung.ac.id/index.php/AKSARA/index

\title{
Meningkatkan Kemampuan Guru-Guru Dalam Membuat Kisi-Kisi Soal Melalui Teknik Kelompok Di SMP Negeri 1 Ponelo Kepulauan
}

\author{
Imran Atute \\ Dinas Pendidikan Dan Kebudayaan \\ Kabupaten Gorontalo Utara \\ Received: 12 Januari 2019; Revised: 26 Februari 2019; Accepted: 28 April 2019 \\ DOI: http://dx.doi.org/10.379 05/aksara.5.3.245-254.2019
}

\begin{abstract}
ABSTRAK
Peningkatan kemampuan guru-guru di SMP Negeri 1 Ponelo Kepulauan dalam dalam membuat tes ditandai dengan penguasaan guru secara optimal terhadap 7 indikator membuat tes mata pelajaran yaitu : a) Kemampuan menganalisis kompetensi dasar dalam kurikulum, b) Kemampuan menganalisis karakteristik siswa, c) Kemampuan analisis dan mengkaji cara membuat tes mata pelajaran, d) Kemampuan mendesain tes mata pelajaran, e) Kemampuan memvalidasi test mata pelajaran, f) Kemampuan mengidentifikasi dan menguji coba tes mata pelajaran dan g) Kemampuan menganalisis hasil tes mata pelajaranTeknik análisis data yang digunakan dalam penelitian ini adalah dengan menjabarkan secara rinci perencanaan, pelaksanaan, pengamatan serta hasil pelaksanaan tindakan setiap siklus sehingga diperoleh gambaran yang jelas tentang hasil penelitian.Berdasarkan hasil analisis ini menunjukkan bahwa terlihat perkembangan yang cukup signifikan dari kemampuan guru-guru di SMP Negeri 1 Ponelo Kepulauandalam membuat test mata pelajaran. Namun demikian kemampuan guru dalam meningkatkan kemampuan guru-guru di SMP Negeri 1 Ponelo Kepulauandalam membuat tes mata pelajaran perlu ditingkatkan karena terdapat 3 kemampuan dalam penyusunan test mata pelajaran yang belum dapat dilaksanakan guru dengan baik.
\end{abstract}

Kata Kunci: Kemampuan Guru dan Teknik Kelompok

\section{PENDAHULUAN}

Peningkatan kemampuan guru dalam membuat tes mata pelajaran merupakan bagian dari kemampuan yang perlu dikuasai guru dalam pembelajaran. Kemampuan membuat tes mata pelajaran perlu dilakukan sebagai upaya untuk menilai kegiatan pembelajaran. Upaya yang dilakukan guru dalam membuat tes mata pelajaran dilakukan sebagai strategi untuk mengetahui perkembangan kemajuan belajar siswa serta untuk menilai keberhasilannya dalam membelajarkan peseta didik. Dalam konteks evaluasi pembelajaran, pembuatan tes mata pelajaran memiliki beberapa tujuan, antara lain sebagai berikut: 1).Untuk mengetahui kemajuan belajar siswa 


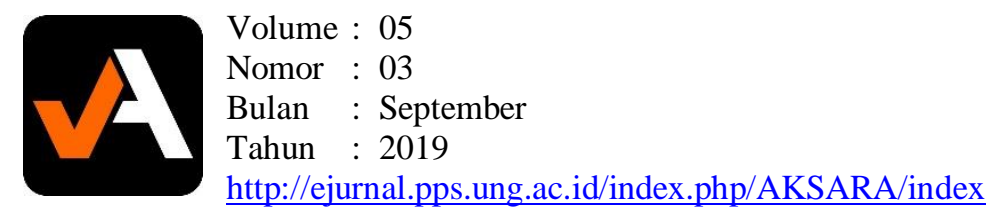

setelah mengikuti kegiatan pembelajaran dalam jangka waktu tertentu. 2).Untuk mengetahui efektivitas metode pembelajaran. 3).Untuk mengetahui kedudukan siswa dalam kelompoknya. Serta 4).Untuk memperoleh masukan atau umpan balik bagi guru dan siswa dalam rangka perbaikan.

Dalam melaksanakan evaluasi pendidikan hendaknya dilakukan secara sistematis dan terstruktur. Sebagaimana telah dikemukakan sebelumnya bahwa evaluasi pendidikan secara garis besar melibatkan 3 unsur yaitu input, proses dan out put. Apabila prosesdur yang dilakukan tidak bercermin pada 3 unsur tersebut maka dikhawatirkan hasil yang digambarkan oleh hasil evaluasi tidak mampu menggambarkan gambaran yang sesungguhnya terjadi dalam proses pembelajaran. Langkah-langkah dalam melaksanakan kegiatan evaluasi pendidikan secara umum adalah sebagai berikut :a. perencanaan (mengapa perlu evaluasi, apa saja yang hendak dievaluasi, tujuan evaluasi, teknikapa yang hendak dipakai, siapa yang hendak dievaluasi, kapan, dimana, penyusunan instrument, indikator, data apa saja yang hendak digali, dsb) b. pengumpulan data (tes, observasi, kuesioner, dan sebagainya sesuai dengan tujuan)c. verifiksi data (uji instrument, uji validitas, uji reliabilitas, dsb) d. pengolahan data ( memaknai data yang terkumpul, kualitatif atau kuantitatif, apakah hendak di olah dengan statistikatau non statistik, apakah dengan parametrik atau non parametrik, apakah dengan manual atau dengan software (misal : SAS, SPSS) e. penafsiran data, (ditafsirkan melalui berbagai teknik uji, diakhiri dengan uji hipotesis ditolak atau diterima, jika ditolak mengapa? Jika diterima mengapa? Berapa taraf signifikannya?) interpretasikan data tersebut secara berkesinambungan dengan tujuan evaluasi sehingga akan tampak hubungan sebab akibat. Apabila hubungan sebab akibat tersebut muncul maka akan lahir alternatif yang ditimbulkan oleh evaluasi itu. Hasil pengamatan menunjukkan bahwa sebagian guru-guru di SMP Negeri 1 Ponelo Kepulauan belum optimal dalam membuat tes mata pelajaran. Kecenderung yang terjadi bahwa tes mata pelajaran yang disusun oleh guru kurang sesuai dengan kaidah penulisan soal. Guru pada umumnya kurang mampu membedakan antara soal pilihan ganda dan essai. Kesulitan ini disebabkan karena kurangya pemahaman guru terhadap kata-kata yang operasional yang digunakan.

\section{KAJIAN TEORETIS}

Test mata pelajaran merupakan bagian dari upaya untuk menilai keberhasilan siswa dalam mempelajari kompetensi dasar yang diajarkan. Tes mata pelajaran merupakan bagian dari kegiatan evaluasi yang dilakukan sebagai umpan balik atas proses pembelajaran yang dilakukan guru. Terkait dengan pengertian evaluasi Menurut Sudirman (2009:23) bahwa kata evaluasi berasal dari Bahasa Inggris evaluation yang berarti penilaian atau penaksiran, edangkan menurut pengertian istilah evaluasi merupakan kegiatan yang terencana untuk mengetahui keadaan sesuatu objek dengan menggunakan instrumen dan hasilnya dibandingkan dengan tolak ukur untuk memperoleh kesimpulan. Evaluasi mengandung pengertian: suatu tindakan atau suatu proses untuk menentukan nilai dari sesuatu. Tujuan evaluasi pendidikan adalah kegiatan atau proses penentuan nilai pendidikan, sehingga dapat diketahui mutu atau 


Volume : 05
Nomor : 03
Bulan : September
Tahun : 2019
http://ejurnal.pps.ung.ac.id/index.php/AKSARA/index

hasil-hasilnya. Dalam proses penilaian, dilakukan perbandingan antara informasiinformasi yang telah berhasil dihimpun dengan kriteria tertentu, untuk kemudian diambil keputusan atau dirumuskan kebijakan tertentu. Kriteria atau tolak ukur yang dipegang tidak lain adalah tujuan yang sudah ditentukan terlebih dahulu sebelum kegiatan pendidikan itu dilaksanakan. Bimbingan kelompok merupakan salah satu teknik bimbingan yang dilakukan untuk meningkatkan kemampuan orang tertentu dalam setiap kelompok. Terkait dengan pengertian bimbingan banyak pendapat yang dikemukakan oleh para ahli diantaranya Natawidjaya (dalam Yusuf dan Nurihsan, 2006:6) mengemukakan bahwa bimbingan sebagai suatu proses pemberian bantuan lepada individu yang dilakukan secara berkesinambungan, supaya individu tersebut dapat memahami dirinya bahwa dia sanggup mengarahkan dirinya dan dapat bertindak secara wajar sesuai dengan tuntutan dan keadaan lingkungan sekolah, keluarga dan masyarakat dan kehidupan pada umumnya. Dengan demikian dia akan dapat menikmati kebahagiaan hidupnya dan dapat memberi sumbangan yang berarti lepada kehidupan masyarakat pada umumnya. Surya (1988:12) berpendapat bahwa bimbingan adalah suatu proses pemberian atau layanan bantuan yang terus menerus dan sistematis dari pembimbing kepada yang dibimbing agar tercapai perkembangan yang optimal dan penyesuaian diri dengan lingkungan.

Oemar Hamalik, (2000:193) mengartikan bimbingan sebagai penolong individu agar dapat mengenal dirinya dan supaya individu itu dapat mengenal serta dapat memecahkan masalah-masalah yang dihadapi di dalam kehidupannya Bimbingan pun dapat diartikan sebagai adalah suatu proses yang terus-menerus untuk membantu perkembangan individu dalam rangka mengembangkan kemampuannya secara maksimal untuk memperoleh manfaat yang sebesar-besarnya, baik bagi dirinya maupun bagi masyarakat. Dari beberapa pendapat di atas dapat ditarik sebuah inti sari bahwa bimbingan dalam penelitian ini merupakan suatu bentuk bantuan yang diberikan kepada individu agar dapat mengembangkan kemampuannya seoptimal mungkin, dan membantu siswa agar memahami dirinya (self understanding), menerima dirinya (self acceptance), mengarahkan dirinya (self direction), dan merealisasikan dirinya (self realization). Hipotesis tindakan dalam penelitian ini adalah jika digunakan teknik bimbingan kelompok maka kemampuan guru-guru di SMP Negeri 1 Ponelo Kepulauan dalam membuat tes di SMP Negeri 1 Ponelo Kepulauankabupaten Gorontalo Utara, provinsi Gorontalo dapat ditingkatkan.

\section{METODE PENELITIAN}

Penelitian ini dilaksanakan di SMP Negeri 1 Ponelo Kepulauan KabupatenGorontalo Utara, provinsi Gorontalo . Penetapan lokasi penelitian didasarkan pada pertimbangan akses dan geografis.Penelitian dilaksanakan selama 3 (tiga) bulan yaitu dari bulan Juli 2018 sampai dengan bulan September 2018. Subjek dalam penelitian ini adalah guru-guru SMP Negeri 1 Ponelo Kepulauan yang ada di Sekolah, SMP Negeri 1 Ponelo Kepulauan kabupaten Gorontalo Utara tersebut.

Prosedur penelitian tindakan kelas ini digambarkan dalam siklus sebagai berikut: 


Volume : 05
Nomor : 03
Bulan : September
Tahun : 2019
http://ejurnal.pps.ung.ac.id/index.php/AKSARA/index

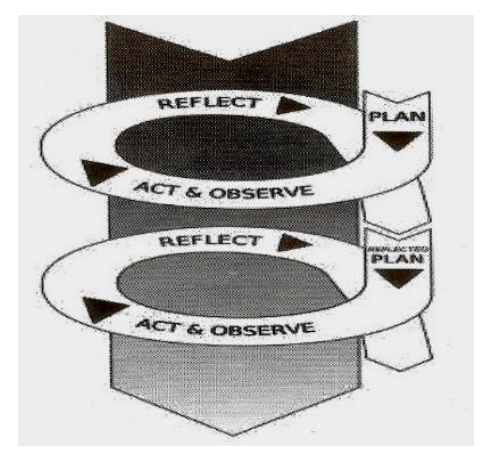

\section{HASIL PENELITIAN DAN PEMBAHASAN}

Penelitian ini dilaksanakan di SMP Negeri 1 Ponelo Kepulauan kabupaten Gorontalo Utara. Kegiatan penelitian dilakukan sebagai upaya untuk meningkatkan kemampuan guru-guru kelas dalam melaksanakan membuat test sehingga menvapai tingkat kualitas bimbingan yang optimal. Terkait hasil pelaksanaan Penelitian yang telah dilaksanakan di SMP Negeri 1 Ponelo Kepulauan kabupaten Gorontalo Utara: Tabel 1. Kemampuan Guru-guru di SMP Negeri 1 Ponelo

\begin{tabular}{|l|c|c|c|}
\hline \multicolumn{1}{|c|}{ Kriteria Aspek yang dinilai } & Baik & Cukup & Kurang Baik \\
\hline $\begin{array}{l}\text { Kemampuan menganalisis kompetensi dasar dalam } \\
\text { kurikulum }\end{array}$ & - & $\sqrt{ }$ & \\
\hline $\begin{array}{l}\text { Kemampuan menganalisis karakteristik siswa } \\
\text { Kemampuan analisis dan mengkaji cara membuat tes } \\
\text { matajaran }\end{array}$ & - & $\sqrt{ }$ & - \\
\hline $\begin{array}{l}\text { Kemampuan mendesain tes mata pelajaran } \\
\text { Kemampuan memvalidasi test mata pelajaran }\end{array}$ & - & - & $\sqrt{ }$ \\
\hline $\begin{array}{l}\text { Kemampuan mengidentifikasi dan menguji coba tes mata } \\
\text { pelajaran }\end{array}$ & - & - & $\sqrt{ }$ \\
\hline $\begin{array}{l}\text { Kemampuan menganalisis hasil tes mata pelajaran } \\
\text { Jumlah }\end{array}$ & & & $\sqrt{ }$ \\
\hline
\end{tabular}

\section{Keterangan:}

Baik

Skor $85-100$
Cukup

Skor 60-84
Kurang Baik

Skor $<59$

Tabel 1 di atas menunjukkan bahwa kemampuan guru-guru di SMP Negeri 1 Ponelo Kepulauan dalam membuat tes sangat rendah hal ini ditunjukkan dengan 


Volume : 05
Nomor : 03
Bulan : September
Tahun : 2019
http://ejurnal.pps.ung.ac.id/index.php/AKSARA/index

rendahnya kemampuan guru dalam menguasai komponen membuat tes mata pelajaran. Dari 2 komponen utama yang diharapkan dapat dikuasai guru ternyata hanya sebanyak 2 komponen (28.57\% yang dapat dikuasai guru dengan kategori cukup) yaitu: kemampuan dalam menganalisis kompetensi dasar dalam kurikulum dan kemampuan menganalisis karakteristik siswa yang diuji.

Tabel 2. Kemampuan Guru-guru di SMP Negeri 1 Ponelo Kepulauan dalamMembuat Tes

Tahap Siklus I

\begin{tabular}{|c|c|c|c|}
\hline Kriteria Aspek yang dinilai & Baik & Cukup & $\begin{array}{c}\text { Kurang } \\
\text { Baik }\end{array}$ \\
\hline $\begin{array}{l}\text { Kemampuan menganalisis kompetensi } \\
\text { dasar dalam kurikulum }\end{array}$ & $\sqrt{ }$ & - & - \\
\hline $\begin{array}{l}\text { Kemampuan menganalisis karakteristik } \\
\text { siswa }\end{array}$ & $\sqrt{ }$ & - & - \\
\hline $\begin{array}{l}\text { Kemampuan analisis dan mengkaji cara } \\
\text { membuat tes mata pelajaran }\end{array}$ & $\sqrt{ }$ & - & - \\
\hline Kemampuan mendesain tes mata pelajaran & $\sqrt{ }$ & & - \\
\hline $\begin{array}{l}\text { Kemampuan memvalidasi test mata } \\
\text { pelajaran }\end{array}$ & - & $\sqrt{ }$ & - \\
\hline $\begin{array}{l}\text { Kemampuan mengidentifikasi dan menguji } \\
\text { coba tes mata pelajaran }\end{array}$ & - & $\sqrt{ }$ & - \\
\hline $\begin{array}{l}\text { Kemampuan menganalisis hasil tes mata } \\
\text { pelajaran }\end{array}$ & - & - & $\sqrt{ }$ \\
\hline Jumlah & 4 & 2 & 1 \\
\hline$\%$ & $57.14 \%$ & $28.57 \%$ & $14.29 \%$ \\
\hline
\end{tabular}

Keterangan:

Baik

Cukup

Skor 60-84

Kurang Baik

Skor $85-100$

Tabel 2 di atas menunjukkan bahwa kemampuan guru dalam membuat tes mata pelajaran setekah dilakukan kegiatan bimbingan kelompok mengalami peningkatan dari observasi awal sebelumnya. Kondisi riil menunjukkan bahwa 4 hal yang telah dilakukan guru dengan baik yaitu : 1) kemampuan menganalisis kompetensi dasar dalam kurikulum, 2) kemampuan menganalisis karakteristik siswa, 3) emampuan analisis dan mengkaji cara membuat tes mata pelajaran, dan 4) kemampuan mendesain tes mata pelajaran. 


Volume : 05
Nomor : 03
Bulan : September
Tahun : 2019
http://ejurnal.pps.ung.ac.id/index.php/AKSARA/index

Namun demikian terdapat 2 kemampuan yang masih dilaksanakan dengan kategori cukup yaitu 1) kemampuan memvalidasi test mata pelajaran, 2) kemampuan mengidentifikasi dan menguji coba tes mata pelajaran. Bahkan terdapat 1 kemampuan yang belum dapat dilaksanakan dengan baik yaitu kemampuan menganalisis hasil tes mata pelajaran. Terkait dengan temuan ini maka akan dilakukan kegiatan penelitian siklus II untuk meningkatkan kemampuan guru dalam membuat test mata pelajaran. Kegiatan siklus II dengan fokus pada upaya perbaikan dan peningkatan kemampuan guru dalam pelaksanaan membuat test mata pelajaran. Melalui upaya ini diharapkan mampu meningkatkan kemampuan guru dalam me membuat test mata pelajaran secara komprehensip mengacu pada 7 indikator membuat test mata pelajaran.

Tabel 3. Kemampuan Guru-guru di SMP Negeri 1 Ponelo Kepulauan dalam Membuat Test

Tahap Siklus II

\begin{tabular}{|l|c|c|c|}
\hline \multicolumn{1}{|c|}{ Kriteria Aspek yang dinilai } & Baik & Cukup & $\begin{array}{c}\text { Kurang } \\
\text { Baik }\end{array}$ \\
\hline $\begin{array}{l}\text { Kemampuan menganalisis kompetensi } \\
\text { dasar dalam kurikulum }\end{array}$ & $\sqrt{ }$ & - & - \\
\hline $\begin{array}{l}\text { Kemampuan menganalisis karakteristik } \\
\text { siswa }\end{array}$ & $\sqrt{ }$ & - & - \\
\hline $\begin{array}{l}\text { Kemampuan analisis dan mengkaji cara } \\
\text { membuat tes mata pelajaran }\end{array}$ & $\sqrt{ }$ & - & - \\
\hline $\begin{array}{l}\text { Kemampuan mendesain tes mata pelajaran } \\
\text { Kemampuan memvalidasi test mata } \\
\text { pelajaran }\end{array}$ & $\sqrt{ }$ & - & - \\
\hline $\begin{array}{l}\text { Kemampuan mengidentifikasi dan menguji } \\
\text { coba tes mata pelajaran }\end{array}$ & $\sqrt{ }$ & - & - \\
\hline $\begin{array}{l}\text { Kemampuan menganalisis hasil tes mata } \\
\text { pelajaran }\end{array}$ & $\sqrt{ }$ & 0 & - \\
\hline \multicolumn{1}{|c|}{ Jumlah } & 7 & 0 & 0 \\
\hline & $100 \%$ & 0 & 0 \\
\hline
\end{tabular}

Keterangan:

Baik

Cukup

Skor 60-84

Kurang Baik

Skor 85 - 100

Tabel 3 di atas menunjukkan bahwa kemampuan guru dalam membuat tes mata pelajaran setekah dilakukan kegiatan bimbingan kelompok mengalami 
peningkatan dari siklus I sebelumnya. Kondisi riil menunjukkan bahwa 7 kemampuan membuat test mata pelajaran semuanya dapat dilakukan dengan baik.

Terkait dengan temuan ini maka penelitian tidak dilanjutkan ke siklus III karena sudah mencapai target yang diharapkan.

\section{Pembahasan}

Salah satu hal yang sangat diperlukan dalam kegiatan evaluasi adalah membuat test. Terkait dengan hal ini maka peningkatan kemampuan guru-guru dalam membuat test terkait mata pelajaran yang diajarkannya harus dilakukan agar guru memiliki kemampuan yang tinggi dalam menyusun test untuk mengukur kualitas siswa dan kualitas pembelajaran yang dilakukan.

Untuk mencapai tujuan-tujuan tersebut, mereka harus memiliki kemampuan sebagai berikut:

1. Kemampuan menganalisis kompetensi dasar dalam kurikulum

2. Kemampuan menganalisis karakteristik siswa

3. Kemampuan analisis dan mengkaji cara membuat tes mata pelajaran

4. Kemampuan mendesain tes mata pelajaran

5. Kemampuan memvalidasi test mata pelajaran

6. Kemampuan mengidentifikasi dan menguji coba tes mata pelajaran

7. Kemampuan menganalisis hasil tes mata pelajaran

Kemampuan tersebut menjadi dasar dalam menyusun .

Berdasarkan hasil penelitian tindakan sekolah yang dilaksanakan selama 2 siklus di SMP Negeri 1 Ponelo Kepulauan kabupatenGorontalo Utara, diperoleh data hasil penelitian terkait peningkatan kemampuan guru dalam membuat test mata pelajaran. Dari kegiatan siklus I menunjukkan bahwa kemampuan guru-guru mata pelajaran dalam membuat tes mata pelajaran mengalami peningkatan dari hasil pengamatan sebelumnya. Dalam konteks ini guru telah dapat membuat test mata pelajaran setelah kegiatan bimbingan kelompok dilakukan. Kondisi riil yang terjadi dari peningkatan kemampuan siswa dalam melakukan kegiatan bimbingan kelompok antara lain ditunjukkan dengan beberapa hal sebagai berikut:

1. Guru-guru di SMP Negeri 1 Ponelo Kepulauan pada umumnya telah mampu melakukan analisis dan identifikasi terhadap kompetensi dasar dalam kurikulum sebagai dasar dalam melakukan kegiatan membuat test mata pelajaran

2. Guru-guru di SMP Negeri 1 Ponelo Kepulauan pada umumnya telah mampu menganalisis karakteristik siswa, mengidentfikasi berbagai hal yang menjadi kebutuhan siswa sebagai dasar dalam menyusun tes mata pelajaran.

3. Guru-guru di SMP Negeri 1 Ponelo Kepulauan pada umumnya mampu menganalisis dan mengkaji cara membuat tes mata pelajaran dengan cara membuat kisi-kisi dan menjabarkan soal sesuai dengan substansinya

4. Guru-guru di SMP Negeri 1 Ponelo Kepulauan pada umumnya mampu mendesain tes mata pelajaran secara sederhana dan mulai dapat menyusun dengan memperhatikan kaidah soal. 


Volume : 05
Nomor : 03
Bulan : September
Tahun : 2019
http://ejurnal.pps.ung.ac.id/index.php/AKSARA/index

\section{PENUTUP} bahwa:

Berdasarkan deskripsi hasil penelitian dan pembahasan, dapat disimpulkan

1. Kemampuan guru-guru di SMP Negeri 1 Ponelo Kepulauan dalam membuat tes mengalami peningkatan setelah dikenai tindakan melalui II siklus.

2. Peningkatan kemampuan guru-guru di SMP Negeri 1 Ponelo Kepulauan dalam dalam membuat tes ditandai dengan penguasaan guru secara optimal terhadap 7 indikator membuat tes mata pelajaran yaitu : a) Kemampuan menganalisis kompetensi dasar dalam kurikulum, b) Kemampuan menganalisis karakteristik siswa, c) Kemampuan analisis dan mengkaji cara membuat tes mata pelajaran, d) Kemampuan mendesain tes mata pelajaran, e) Kemampuan memvalidasi test mata pelajaran, f) Kemampuan mengidentifikasi dan menguji coba tes mata pelajaran Saran dan g) Kemampuan menganalisis hasil tes mata pelajaran.

Dari hasil penelitian tindakan kelas ini, maka dapat dikemukakan saran-saran sebagai berikut:

1) Kegiatan bimbingan kelompok perlu dilakukan secara rutin untuk membantu peningkatan kompetensi guru-guru di SMP Negeri 1 Ponelo Kepulauan dalam menyusun tes.

2) Guru-guru di SMP Negeri 1 Ponelo Kepulauan perlu mengembangkan kemampuannya dalam membuat tes melalui kegiatan latihan terbimbing maupun mandiri yang dilaksanakan secara rutin.

3) Kepada peneliti lanjutan di sarankan agar mengadakan penelitian ini dalam populasi yang lebih besar.

\section{DAFTAR PUSTAKA}

Ahmad. 2010. Bimbingan kelompok. Tersedia di http.://gurupembaharu.com/home/ $? \mathrm{p}=4388$. (Download) 2 Pebruari 2010

Arikunto, Suharsimi, 2002, Prosedur Penelitian Suatu Pendekatan praktek .Jakarta : Rineka Cipta

Depdiknas, 1998. Manajemen Sekolah. Jakarta : Direktorat Jenderal Pendidikan Dasar dan Menengah

Indrayanto. 2010. Bimbingan kelompok. (Online). Tersedia dihttp://id.shvoong.com/ social-sciences/education/2025213-supervisi-akademik/. (Download, 2 Pebruari 2010)

Indrayanto. 2010.Prinsip-prinsip Bimbingan kelompok. Tersedia dihttp://id.shvoong. com/social-sciences/education/2025215-prinsip-prinsip-supervisiakademik/.(Download, 2 Pebruari 2010)

Nurihsan Juntika Ahmad. 2005. Strategi Layanan Bimbingan kelompok. Jakarta: PT Rafika Aditama. 


Volume : 05
Nomor : 03
Bulan : September
Tahun : 2019
http://ejurnal.pps.ung.ac.id/index.php/AKSARA/index

Nurihsan Juntika dan Yusuf Syamsu. 2007. Landasan Bimbingan kelompok. Bandung: Program Pasca Sarjana Universitas Pendidikan Indonesia dan PT Remaja Rosda Karya

Moleong. 2001 Metodologi Penelitian Kualitatif. Cet XIII. Bandung: Remaja Rosdakarya

M. Surya. 1988. Pengantar Bimbingan dan Penyuluhan. Jakarta : UT.

Oemar Hamalik. 2000. Psikologi Belajar dan Mengajar. Bandung: Sinar Baru Algensindo.

Prayitno Erman Amti. 1997. Dasar-dasar Bimbingan kelompok. Jakarta: Depdikbud.

Rustantiningsih.2007.Peran Guru Kelas Dalam Pelaksanaan Bimbingan Bimbingan di sekolah Dasar (Online) Tersedia di http://researchengines.com/rustianti 40708 . htm. (Download, 2 Pebruari 2010)

Sardiman. 2001. Interaksi dan Motivasi Belajar-Mengajar. Jakarta: Raja Grafindo Persada.

Sudirman.2009.Evaluasi Hasil Belajar. Jakarta. Haparan. Masa.

Sudjana. 2010. Pembinaan dan Pengembangan Karir Pengawas Sekolah. (Online). Tersedia di http://akhmadsudrajat.wordpress.com/2008/04/13/pembinaan-danpengembangan-karir-pengawas-sekolah/. . (Download, 2 Pebruari 2010)

Sudradjat Akhmad. 2007. Kesulitan Belajar Siswa dan Bimbingan Belajar (Online) Tersedia di http/www.kes.rtti.,com.press.html

Tim Pengembangan MKDK IKIP Semarang. 1990. Bimbingan kelompok Sekolah. Semarang: IKIP Semarang Press. 